Vol. 7(1998): 345-356.

\title{
Evaluation of the spot urine sampling technique to assess urinary pseudouridine excretion in lactating dairy cows
}

\author{
Kevin J. Shingfield \\ Grassland and Ruminant Science Department, SAC Auchincruive, Ayr, KA6 5HW, United Kingdom, Current \\ address: Agricultural Research Centre of Finland, Animal Production Research, FIN-31600 Jokioinen, \\ Finland, e-mail: kevin.shingfield@mtt.fi \\ Nicholas. W. Offer \\ Grassland and Ruminant Science Department, SAC Auchincruive, Ayr, KA6 5HW, United Kingdom
}

\begin{abstract}
The potential of the spot urine sampling technique to assess urinary pseudouridine excretion was evaluated. Twelve multiparous Holstein-Friesian cows were fed two experimental diets in a complete change-over design with two 14 day experimental periods. Diets were either silage fed ad libitum with a concentrate supplement offered as a single meal (SF), or a complete diet formulated from the same ingredients (CD). Total urine collections were performed for $24 \mathrm{~h}$ at $2 \mathrm{~h}$ intervals on days 11 and 14. Pseudouridine and creatinine excretion during each $2 \mathrm{~h}$ interval depended on time of collection (pseudouridine, $\mathrm{P}<0.001$ and creatinine, $\mathrm{P}<0.05$ ) and on cow (pseudouridine, $\mathrm{P}=0.092$ and creatinine, $\mathrm{P}<0.01$ ), but were unaffected by differences due to sampling day or treatment. Variations in the molar ratio of pseudouridine to creatinine (Ps/c) followed similar diurnal patterns observed for pseudouridine excretion. Data was used to assess the accuracy of spot urine sampling to predict daily mean Ps/c ratios. Collection of multiple samples within a day was more reliable than collecting fewer samples over several days, while prediction errors were generally greater for CD compared to SF. Even the most intensive sampling regimen did not allow an acceptable prediction of the daily mean $\mathrm{Ps} / \mathrm{c}$ ratio, minimum $\mathrm{r}$ values 0.528 and 0.080 for $\mathrm{SF}$ and $\mathrm{CD}$ treatments, respectively. Furthermore, mean $\mathrm{Ps} / \mathrm{c}$ ratios accounted for only half of the variation observed in daily pseudouridine excretion. A total urine collection appears necessary to assess accurately daily pseudouridine excretion in dairy cows.
\end{abstract}

Key words: creatinine, dairy cows, pseudouridine, spot sampling

\section{Introduction}

During early lactation, body fat reserves are mobilised in the dairy cow to support milk pro- duction, while body protein content may also decrease (Gibb et al. 1992), the extent of which may be greater during protein deficiency (Botts et al. 1979). The importance of labile protein reserves on subsequent lactation performance has

(C) Agricultural and Food Science in Finland Manuscript received November 1997 


\section{AGRICULTURAL AND FOOD SCIENCE IN FINLAND}

Shingfield, K.J. \& Offer, N.W. Assessment of pseudouridine excretion by spot urine sampling

recently been demonstrated in dairy cows (Moorby et al. 1996). Condition scoring is often used to estimate body fat content but is of little value as an indicator of nitrogen status since it accounts only poorly for variations in carcass composition.

Pseudouridine is one of the most important modified pyrimidine derivative constituents of both transfer and ribosomal RNA (Sander et al. 1986a). Pseudouridine liberated during tissue RNA degradation is not salvaged, but obligately excreted in the urine (Weissman et al. 1962). Schöch et al. (1982) suggested that urinary pseudouridine excretion reflects RNA turnover and could therefore be used as a marker of protein synthesis (Sander et al. 1986b), assuming these processes are directly related. In cattle, pseudouridine excreted in urine is positively correlated with growth rate in young animals, and could potentially be used as an index of nitrogen status (Puchala et al. 1993). Urinary creatinine excretion has been proposed as an internal marker of urinary output (e.g. Erb et al. 1977), and therefore the possibility exists of assessing pseudouridine excretion from the molar ratio of pseudouridine to creatinine (Ps/c) of spot urine samples. The current study was conducted to evaluate the accuracy of the spot urine sampling technique to assess urinary pseudouridine excretion. Data from this study used to evaluate the accuracy of this approach to assess urinary purine derivative excretion has previously been reported (Shingfield and Offer 1998).

\section{Material and methods}

\section{Animals and management}

Twelve multiparous lactating Holstein-Friesian cows of mean live weight $611 \mathrm{~kg}$ (s.e. 19.5) were housed in individual stalls within the dairy cow metabolism unit at SAC, Auchincruive. Cows were retained in each stall with de Boer yokes. Each stall was fitted with a rubber mat and bed- ded with sawdust. Animals had continual access to water and were milked in situ at approximately 0700 and 1500 .

\section{Experimental diets}

Since the spot sampling technique would be applied in practice over a range of diets and feeding strategies, experimental diets were formulated to examine the effect of feeding frequency on the accuracy of spot urine sampling. Differences in feeding frequency were achieved by feeding silage and a standard concentrate either separately (treatment SF) or as a complete diet (treatment CD). Diets were formulated from a first cut silage ensiled during may 1992 from grass swards in which perennial ryegrass predominated, supplemented with $7 \mathrm{~kg}$ fresh weight $/ \mathrm{d}$ of a standard concentrate to meet metabolisable energy (ME) and metabolisable protein requirements (AFRC 1992) using SAC advisory rationing software (N.W. Offer, pers. comm.). The same software was used to predict ad libitum silage intake allowing treatment $\mathrm{CD}$ to be formulated to the same forage:concentrate ratio (62:38, on a dry matter basis) as for SF. CD was prepared in $600 \mathrm{~kg}$ fresh weight batches on a daily basis using a Keenan (Richard Keenan Company Limited, Co. Carlow, Eire) diet feeder. Fresh silage and CD were offered at 0800 and topped up as and when necessary to ensure $10 \%$ refusals. Concentrate was offered at 1000 and was consumed rapidly, typically within $90 \mathrm{~min}$ utes.

\section{Experimental design}

Experimental treatments were evaluated using a complete change-over design. Cows were grouped into two blocks of six animals, according to calving date, parity and live weight. Mean days in lactation, live weight $(\mathrm{kg})$ and parity were 148,610 (s.e. 22.3), 4.3; and 148, 613 (s.e. 34.4 ) and 3.8 , for blocks 1 and 2, respectively. Each experimental period lasted for 14 days with 


\section{AGRICULTURAL AND FOOD SCIENCE IN FINLAND}

Vol. 7 (1998): 345-356.

measurements performed on days 11 and 14 . Use of a 10 day rumen adaptation period was considered adequate since all experimental animals had previously been fed the same silage and concentrate.

\section{Measurements and sampling}

Milking and feed sampling protocols have previously been reported (Shingfield and Offer 1998). Cows were weighed at the beginning and end of each 14 day experimental period at 1000 . On days 11 and 14 of each experimental period, $2 \mathrm{~h}$ urine collections were performed over a $24 \mathrm{~h}$ period, starting at 0800 . Urine collection was achieved by inducing cows to urinate by vulval stimulation. This procedure was repeated $3 \mathrm{~min}$ later to minimise end of collection errors. The volume of urine voided for each $2 \mathrm{~h}$ collection was measured, while sub-samples were taken and stored at $-20^{\circ} \mathrm{C}$. Cows were observed constantly to ensure a total urine collection for each animal was achieved.

\section{Chemical analyses}

Chemical composition (organic matter, crude protein, starch, neutral cellulase and gamminase digestibility and acid hydrolysis ether extract of feeds was determined using standard procedures described by Dewhurst et al. (1996). Concentrate ME content was calculated from neutral cellulase and gamminase digestibility and acid hydrolysis ether extract measurements according to equation E3 (Thomas et al. 1988). Silage in vitro organic matter digestibility measurements made using a modified (Alexander 1969) Tilley and Terry (1963) method were used to predict silage ME (MAFF 1975). Urinary pseudouridine and creatinine concentrations were determined by High Perfomance Liquid Chromatography (Shingfield and Offer 1998). Separation was achieved using a Spherisorb $5 \mu \mathrm{m}$ ODS II C-18 reversed-phase column ( $250 \mathrm{~mm}$ x $4.6 \mathrm{~mm}$ i,d,; Phase Separations Ltd, Deeside, Clwyd) eluted with a mobile phase $(7.5 \mathrm{mM}$ phosphate buffer, $10 \mathrm{mM}$ sodium 1-heptanesulphonic acid, $1.0 \mathrm{mM}$ triethylamine adjusted to $\mathrm{pH} 3.0$ using $10 \%(\mathrm{v} / \mathrm{v})$ hydrochloric acid) at a flow rate of $1.0 \mathrm{ml} / \mathrm{min}$ and temperature $20^{\circ} \mathrm{C}$, while peaks were detected at $218 \mathrm{~nm}$. Average recovery of pseudouridine and creatinine standards added to urine was above $90 \%$ while within and betweenday variability was less than $4 \%$.

\section{Statistical analysis}

Statistical analysis of all experimental data was performed using GENSTAT 5 (version 5.3., Lawes Agricultural Trust, 1987). With experimental data collected at regular intervals within a period of time, the problem arises of dependence of a measurement on previous observations. Two-hourly pseudouridine and creatinine (both excretion and concentration) and the molar ratio of pseudouridine to creatinine (Ps/c) data was tested for dependence, using "antorder" anttest procedures (Gabriel 1962, Kenward 1987) which fit data to a model which takes dependence into account. Results of the "antorder" procedures showed that there was no evidence to support the fitting of a repeated measures model to the data. Consequently, a split-split-plot analysis of variance was used to test the effects of cow and diet (whole-plot factors), sampling day (sub-plot factor), sampling hour (sub-sub-plot factor) and their interactions using the following model:$\{$ blocking structure $=($ cow $\times$ period $/$ day $/ \mathrm{hr})$ and treatment structure $=($ cow $\times$ day $)+($ diet $\times$ hr $)\}$.

The accuracy of spot urine sampling methods were assessed using daily mean Ps/c ratios obtained by total urine collection (i.e. sum of all $2 \mathrm{~h}$ collections) for each cow as reference values. Initially, Ps/c ratios determined from spot samples at each $2 \mathrm{~h}$ sampling $(\mathrm{n}=12)$ were compared with reference values for each group of experimental animals for each period (i.e. 12 measurements) producing 52 correlations. However, in practice more than one spot sample would be collected to assess the daily mean. Consequently, spot sampling regimens based on 


\section{AGRICULTURAL AND FOOD SCIENCE IN FINLAND}

Shingfield, K.J. \& Offer, N.W. Assessment of pseudouridine excretion by spot urine sampling

Table 1. Chemical composition of silage, concentrate and complete diet ( $\mathrm{g} / \mathrm{kg}$ dry matter (DM) unless otherwise stated).

\begin{tabular}{lccc}
\hline & Silage & Complete diet & Concentrate \\
\hline Dry matter (g/kg Fresh weight) & 298 & 363 & 876 \\
Corrected dry matter (DM; g/kg FW) & $321^{(1)}$ & $\mathrm{ND}$ & $\mathrm{ND}$ \\
$\mathrm{pH}$ & 3.9 & 4.2 & $\mathrm{ND}$ \\
Ammonia-nitrogen (g/kg total N) & 103 & 92.5 & $\mathrm{ND}$ \\
Composition of DM & & & \\
Crude protein & 180 & 180 & 207 \\
Ash & 83 & 81 & 90 \\
Neutral cellulase and gammanase digestibility & $\mathrm{ND}$ & $\mathrm{ND}$ & 782 \\
In vitro organic matter digestibility (g/kg OM) & 764 & $\mathrm{ND}$ & $\mathrm{ND}$ \\
Acid hydrolysed ether extract & 53.3 & 65.6 & 95.7 \\
Metabolisable energy (MJ/kg DM) & $11.6^{(2)}$ & $11.8^{(3)}$ & $13.4^{(4)}$ \\
\hline
\end{tabular}

(1) Dry matter corrected for loss of volatiles (Shingfield and Offer 1998)

(2) calculated according to MAFF (1975)

(3) calculated using DM and ME values of silage and concentrate

(4) calculated according to the equation of Thomas et al. (1988)

ND $=$ Not determined

2 samples collected at $12 \mathrm{~h}$ intervals $(12 \mathrm{~h}$ scheme), 3 samples collected at $8 \mathrm{~h}$ intervals ( $8 \mathrm{~h}$ scheme) and 4 samples collected at $4 \mathrm{~h}$ intervals ( $4 \mathrm{~h}$ scheme) were evaluated. Sampling regimen Ps/c estimates were derived using all data collected during the $24 \mathrm{~h}$ collection period and were correlated with the measured (by total urine collection) daily mean $\mathrm{Ps} / \mathrm{c}$ ratio, for each cow within a group for both sampling days within a period. To assess the increase in accuracy from using two sampling days, the process described above was repeated using data from both sampling days. Exploratory data handling and regression analysis were undertaken using MINITAB statistical software (Minitab Inc. 1980).

\section{Results}

\section{Animal production}

Chemical composition of silage, concentrate and complete diet is shown in Table 1. Mean treatment effects on dry matter, crude protein and ME intake or milk yield and composition were not significant $(\mathrm{P}>0.05$; Table 2$)$. Mean cow live weights $(\mathrm{kg})$ were 615 and 617 for treatments $\mathrm{SF}$ and $\mathrm{CD}$ respectively $(\mathrm{P}>0.05)$.

\section{Urinary pseudouridine concentration and excretion}

The effect of dietary treatment on daily mean urinary pseudouridine concentration of 437 and 439 (s.e.d. 14.9) $\mu \mathrm{mol} / \mathrm{l}$, for SF and CD treatments, respectively or daily excretion of 8.06 and 8.33 (s.e.d. 0.33) mmoles/day, for SF and CD treatments, respectively were not significant (P values of 0.909 and 0.431 , respectively). Twohourly pseudouridine concentration was significantly affected by cow $(\mathrm{P}<0.001)$, sampling time $(\mathrm{P}<0.001)$ and by treatment $\mathrm{x}$ sampling time interactions $(\mathrm{P}<0.05)$, Mean $(\mathrm{n}=24) 2 \mathrm{~h}$ pseudouridine concentration varied diurnally between 346-561 and 344-548 $\mu \mathrm{mol} / \mathrm{l}$ for SF and CD treatments, respectively.

Two-hourly pseudouridine excretion was significantly different between sampling times $(\mathrm{P}<0.001)$ and by interactions between treatment and sampling times $(\mathrm{P}<0.05)$, while differences due to cow approached significance $(\mathrm{P}<0.092)$. 


\section{AGRICULTURAL AND FOOD SCIENCE IN FINLAND}

Vol. 7 (1998): 345-356.

Fig. 1. Diurnal variation in urinary pseudouridine excretion for cows offered concentrate separately (- - ) or as a complete diet (- - Each point is the mean of 24 observations with s.e. Lines without markers indicate treatment daily means.

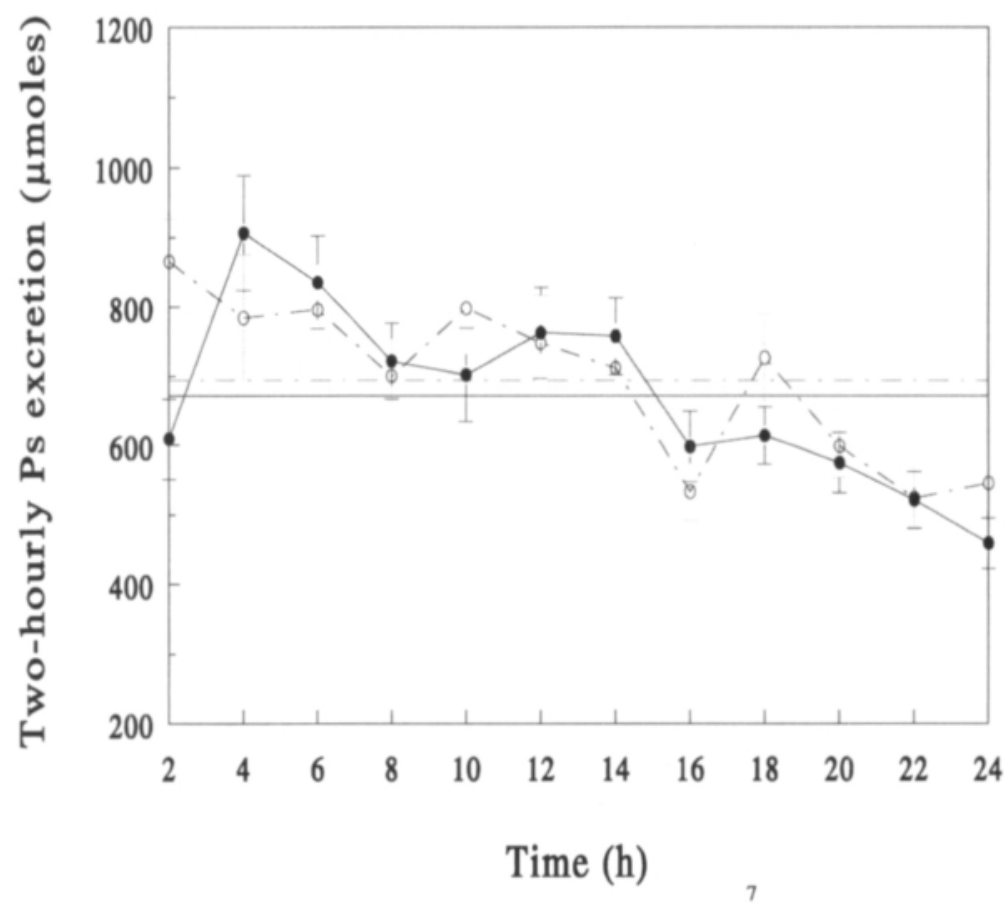

ed with daily mean pseudouridine concentration $(\mathrm{r}=0.500, \mathrm{n}=48, \mathrm{P}<0.05)$ and metabolic live weight $(r=0.299, n=48, P<0.05)$. Coefficients of variation (CV) due to the effects of cow, experimental period, sampling day and sampling time on urinary pseudouridine concentration and excretion are shown in Table 3.

Table 2. Effect of dietary treatment on nutrient intake, milk production and urinary output.

\begin{tabular}{lcccc}
\hline Daily intake & Separate feeding & Complete diet & SED & P \\
\hline Total dry matter intake (kg) & 20.1 & 19.8 & 0.557 & $>0.05$ \\
Crude protein (g) & 3558 & 3569 & 98.5 & $>0.05$ \\
Metabolisable energy (MJ) & 245 & 234 & 7.1 & $>0.05$ \\
Milk yield and composition & & & & \\
Milk yield (kg) & 28.8 & 27.5 & 0.61 & $>0.05$ \\
Fat $(\mathrm{g} / \mathrm{kg})$ & 39.7 & 37.0 & 1.76 & $>0.05$ \\
Protein (g/kg) & 30.8 & 31.0 & 0.22 & $>0.05$ \\
Lactose (g/kg) & 47.4 & 46.4 & 2.17 & $>0.05$ \\
Fat (g/d) & 1149 & 1037 & 90.7 & $>0.05$ \\
Protein (g/d) & 889 & 850 & 56.7 & $>0.05$ \\
Lactose (g/d) & 1361 & 1275 & 87.0 & $>0.05$ \\
Urinary output (l/d) & 19.1 & 19.9 & 0.36 & $>0.05$ \\
\hline
\end{tabular}


Shingfield, K.J. \& Offer, N.W. Assessment of pseudouridine excretion by spot urine sampling

Table 3. Coefficients of variation $(\mathrm{CV} \%)$ for concentration and daily excretion of pseudouridine and creatinine and $\mathrm{Ps} / \mathrm{c}$ ratios.

\begin{tabular}{|c|c|c|c|c|c|}
\hline & & \multicolumn{4}{|c|}{ Source of variation } \\
\hline & & Cow & Sampling period & Sampling day & Sampling hour \\
\hline \multicolumn{6}{|c|}{ Concentration } \\
\hline & Pseudouridine & 16.8 & 8.1 & 18.5 & 41.1 \\
\hline & Creatinine & 18.3 & 6.4 & 13.0 & 34.5 \\
\hline \multicolumn{6}{|c|}{ Excretion } \\
\hline & Pseudouridine & 10.5 & 9.1 & 17.0 & 41.6 \\
\hline & Creatinine & 15.4 & 7.8 & 9.1 & 32.3 \\
\hline \multicolumn{6}{|l|}{ Ratio } \\
\hline & $\mathrm{Ps} / \mathrm{c}$ & 10.8 & 6.5 & 10.8 & 27.3 \\
\hline
\end{tabular}

\section{Diurnal variation in urinary Ps/c ratio}

Urinary creatinine concentrations reported previously (Shingfield and Offer 1998) were used to calculate Ps/c ratios. Use of creatinine as an internal marker of urinary output reduced variations in pseudouridine concentration between sampling days and sampling intervals (Table 3).

Daily mean Ps/c ratios were not significantly different between treatments $(\mathrm{P}=0.785$, mean 0.062 and 0.063 (s.e.d. 0.002 ) for SF and CD treatments, respectively) or sampling days $(\mathrm{P}=0.171$, mean 0.061 and 0.064 (s.e.d. 0.002$)$ for days 1 and 2, respectively). In contrast, daily mean $\mathrm{Ps} / \mathrm{c}$ ratios were significantly different between cows $(\mathrm{P}<0.01)$ and were negatively correlated with metabolic live weight $(r=-0.59, \mathrm{n}$ $=48, \mathrm{P}<0.001)$. Mean two-hourly Ps/c ratios were significantly influenced by sampling time $\mathrm{x}$ treatment interactions $(\mathrm{P}<0.05)$ and were significantly different between sampling times $(\mathrm{P}<0.001)$, ranging between 0.051 to 0.091 and 0.054 to 0.076 for SF and CD treatments, respectively (Figure 2).

\section{Accuracy of spot sampling for assessing daily $\mathrm{Ps} / \mathrm{c}$ ratios}

Accuracy of the spot sampling technique was initially assessed by comparing estimates of Ps/c ratios from individual spot samples collected at each sampling interval with the daily mean obtained by total urine collection. Correlations between daily mean Ps/c ratios and estimates based on the collection of single spot samples (Figure 3) were generally poor (mean $r$ value 0.558 ), while differences due to treatment were inconsistent between sampling intervals (mean $r$ values 0.593 and 0.523 for treatments SF and $\mathrm{CD}$, respectively).

In practice however, more than one spot sample would be used to assess daily mean Ps/c ratios. Consequently three multiple sampling methods were evaluated. Mean Ps/c ratios were derived from the appropriate spot samples for each sampling regimen and compared to the daily mean obtained by total urine collection (Table 4). This process was repeated using estimates based on spot samples obtained over two sampling days to investigate whether accuracy could be improved by extending the observation period. Collection of multiple spot samples within a day improved correlations between spot sample estimates and the reference mean, while only minor improvements in spot sampling accuracy were achieved by collecting urine over two days. The most intensive sampling regimen (4-h sampling) gave average correlations (across both SF and CD treatments) of 0.824 and 0.743 based on single and two day urine collections, respectively, while respective minimum values were 0.679 and 0.075 . 
Vol. 7 (1998): 345-356.

Fig. 2. Diurnal variation in the molar ratio of urinary pseudouridine to creatinine for cows offered concentrate separately ( $-\mathbf{-}$ ) ) or as a complete diet (-O- Each point is the mean of 24 observations with s.e. Lines without markers indicate treatment daily means.

Fig. 3. Correlation coefficients between $\mathrm{Ps} / \mathrm{c}$ ratio in spot urine samples taken at different times and the mean daily $\mathrm{Ps} / \mathrm{c}$ measured by total collection $(n=12$; mean of two correlations, range shown as error bars).
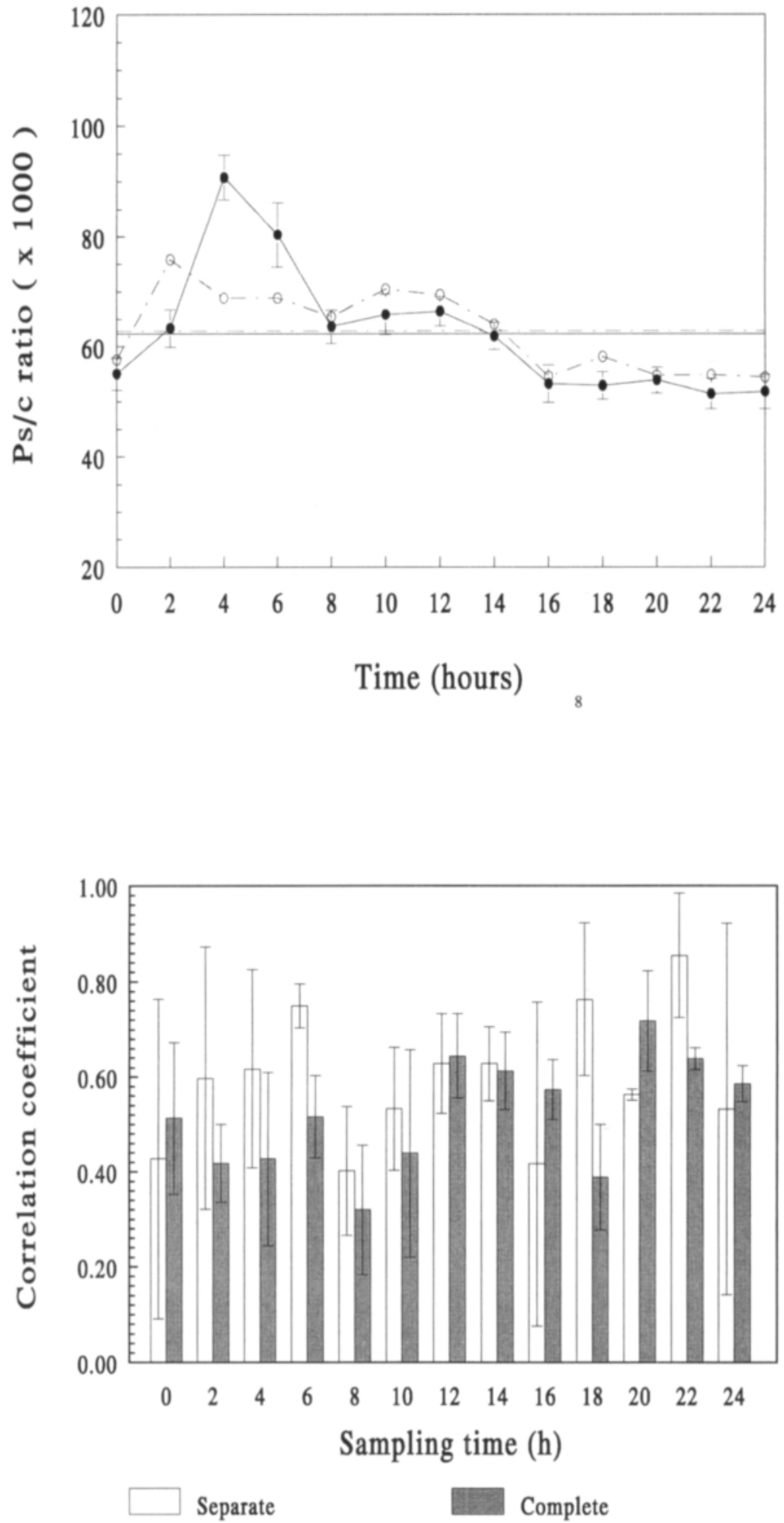


\section{AGRICULTURAL AND FOOD SCIENCE IN FINLAND}

Shingfield, K.J. \& Offer, N.W. Assessment of pseudouridine excretion by spot urine sampling

Table 4. A summary of correlation coefficients derived between sampling regimen estimates and daily mean $\mathrm{Ps} / \mathrm{c}$ ratios.

\begin{tabular}{lcccccccc}
\hline $\begin{array}{l}\text { Sampling } \\
\text { regimen (hours) }\end{array}$ & $\begin{array}{c}\text { Number of } \\
\text { sampling days }\end{array}$ & Number of & \multicolumn{3}{c}{ Separate feeding } & \multicolumn{3}{c}{ Complete diet feeding } \\
correlations & Min & Max & Mean & Min & Max & Mean \\
\hline 12 & 1 & $14^{1}$ & 0.348 & 0.922 & 0.615 & 0.506 & 0.837 & 0.618 \\
8 & 1 & $10^{1}$ & 0.602 & 0.957 & 0.798 & 0.579 & 0.903 & 0.740 \\
4 & 1 & $14^{1}$ & 0.708 & 0.931 & 0.848 & 0.679 & 0.896 & 0.800 \\
12 & 2 & $14^{2}$ & 0.357 & 0.953 & 0.744 & 0.185 & 0.988 & 0.575 \\
8 & 2 & $10^{2}$ & 0.648 & 0.981 & 0.869 & 0.075 & 0.967 & 0.654 \\
4 & 2 & $14^{2}$ & 0.528 & 0.986 & 0.839 & 0.080 & 0.946 & 0.647 \\
\hline
\end{tabular}

' Correlations were derived using 12 units of data, obtained from 6 cows for both sampling days within each period

${ }^{2}$ Correlations were derived using 6 units of data, obtained from the mean of both sampling days within each period for each cow

Mean $r$ values based on a single sampling day were relatively similar for both treatments (Table 4), while mean $r$ values based on two-day urine collections were higher for treatment SF. Minimum $r$ values were higher for treatment $\mathrm{SF}$ for every sampling method tested, except for 12 h sampling based on a single day urine collection.

\section{Relationship between urinary pseudourid- ine excretion and $P s / c$ ratios}

Daily mean Ps/c ratios obtained by total urine collection were poorly correlated with daily pseudouridine excretion $(\mathrm{r}=0.360, \mathrm{n}=48$, $\mathrm{P}<0.05$; Table 5). The most accurate prediction

Table 5. Relationships between scaled daily mean molar ratios of pseudouridine to creatinine (Ps/c) with pseudouridine excretion.

\begin{tabular}{lcc}
\hline $\begin{array}{l}\text { Weighting } \\
\text { factor }\end{array}$ & $\mathrm{r}$ & $\mathrm{Ps} / \mathrm{c}$ \\
\hline None & 0.36 & $<0.05$ \\
Creatinine concentration & 0.62 & $<0.001$ \\
Metabolic live weight & 0.56 & $<0.001$ \\
Live weight & 0.62 & $<0.001$ \\
Live weight squared & 0.70 & $<0.001$ \\
Live weight and creatinine & & \\
concentration & 0.40 & $<0.01$ \\
Creatinine excretion & 0.98 & $<0.001$ \\
\hline
\end{tabular}

of pseudouridine excretion was attained by weighting daily mean Ps/c data by daily urinary creatinine excretion for each individual cow. Adopting this approach is however impractical since assessment of urinary creatinine excretion requires a total urine collection. Weighting daily mean Ps/c ratios of individual cows by urinary creatinine concentration, live weight or metabolic live weight improved the prediction of urinary pseudouridine excretion. Use of live weight as a weighting factor gave a relationship which accounted for approximately half the variation in pseudouridine excretion.

\section{Discussion}

Since, milk production, urinary purine derivative and creatinine excretion data has been discussed previously (Shingfield and Offer 1998), discussion is confined to examination of the sources of variation of urinary psuedouridine excretion and evaluation of the accuracy of the spot sampling technique to assess it.

\section{Urinary pseudouridine excretion}

Urinary pseudouridine excretion varied diurnally, the extent of which was similar for both sep- 


\section{AGRICULTURAL AND FOOD SCIENCE IN FINLAND}

Vol. 7 (1998): 345-356.

arate and complete diet feeding. Chen et al. (1992) adopted a similar approach used in the current study and attributed observed diurnal variations in urinary purine derivative excretion to end-of-urine collection errors. End-of-urine collection errors were minimised in the current study by inducing cows to urinate twice at each collection interval. Furthermore, bias which may be introduced as a result of systematic analytical error was minimised by analysing samples in random sequence.

Pseudouridine derived during RNA turnover is not salvaged or further metabolised (Borek et al. 1977, Gehrke et al. 1979) but excreted in urine. Since its excretion is independent of levels contained in the diet (Weissman et al. 1962) or duodenal nucleic acid flow (Puchala et al. 1993), observed variations in urinary pseudouridine excretion may reflect diurnal changes in tissue RNA turnover rates.

Daily urinary pseudouridine losses of 65.6 (s.e. 1.9) and 67.7 (s.e. 2.6) $\mu \mathrm{mol} / \mathrm{kg} \mathrm{W}^{0.75}$, (SF and $\mathrm{CD}$ treatments, respectively) were double those reported by Puchala et al. (1993) for heifers $\left(30.8\right.$ to $\left.36.4 \mu \mathrm{mol} / \mathrm{kg} \mathrm{W}^{0.75}\right)$ and three times higher than values for non-lactating cows (19.5 to $21.6 \mu \mathrm{mol} / \mathrm{kg} \mathrm{W}^{0.75}$ ). Discrepancies between these findings may potentially be explained by metabolic processes occurring during lactation rather than due to secretion in milk per se, since milk protein synthesis is estimated to account for at least $20 \%$ of whole-body synthesis in a cow yielding $22 \mathrm{~kg}$ milk/d (Oldham et al. 1980) and pseudouridine secretion in milk is thought to be closely related to protein synthesis in the mammary gland (Rosskopf et al. 1991). Based on assumed milk pseudouridine concentrations of $4 \mu \mathrm{mol} / \mathrm{l}$ (Tiemeyer et al. 1984, Rosskopf et al. 1991), daily mammary secretion may have currently accounted for pseudouridine losses approaching $1.0 \mu \mathrm{mol} / \mathrm{kg} \mathrm{W}^{0.75}$.

Other studies have demonstrated that urinary pseudouridine excretion increases during late pregnancy (Martín Orúe et al. 1995) and growth (Puchala et al. 1993) both of which were attributed to elevated tissue turnover of RNA and tRNA (the major source of pseudouridine) in particular, associated with a higher rate of protein synthesis. Comparison of daily urinary pseudouridine excretion reported for lactating (12.9 $\mu \mathrm{mol} / \mathrm{kg} \mathrm{W}{ }^{0.75}$, Martín Orúe et al. 1996) and non-lactating $\left(20.4 \mu \mathrm{mol} / \mathrm{kg} \mathrm{W}^{0.75}\right.$, Puchala et al. 1993) adult ewes suggest that physiological factors other than lactation per se may also be involved.

Changes in body composition of dairy cows during the first 29 weeks of lactation indicate that daily net losses of crude protein approach $0.1 \mathrm{~kg}$ during the first eight weeks post partum (Gibb et al. 1992). Despite a relatively large depletion of crude protein from the carcass $(0.123$ $\mathrm{kg} / \mathrm{d}$ ) and smaller net losses from the udder and urino-genital tract $(0.019 \mathrm{~kg} / \mathrm{d})$ during this period, protein was accreted in the liver and digestive tract $(0.006$ and $0.010 \mathrm{~kg} / \mathrm{d}$, respectively). Examination of changes in body composition indicated that throughout the first 29 weeks of lactation, protein was accreted in the liver, gut, heart, respiratory tract and spleen, tissues which have a high fractional rate of protein synthesis. Assuming that pseudouridine distribution and turnover is similar between and within mammalian species (Kahn et al. 1978), and that its excretion reflects RNA turnover (Schöch et al. 1982) and consequently protein synthesis (Sander et al. 1986b), changes in body composition occurring during lactation may account for discrepancies in urinary pseudouridine excretion between animals in different physiological states.

\section{Diurnal variation in the $\mathrm{Ps} / \mathrm{c}$ ratio}

Use of creatinine as an internal marker of urinary output reduced variations in pseudouridine concentrations between sampling times which is consistent with other studies (Chen et al. 1992, Gonda and Lindberg 1994). Within-day variations in urinary Ps/c ratios followed diurnal patterns for both experimental diets, the extent of variation being greater for separate feeding. This finding suggests that limitations in the number of spot samples that could be collected in practice would lead to difficulties in establishing a 
Shingfield, K.J. \& Offer, N.W. Assessment of pseudouridine excretion by spot urine sampling

valid sampling protocol which would be accurate for a range of diets and feeding systems.

\section{Accuracy of prediction of daily Ps/c ratios from spot samples}

Mean, minimum and maximum correlation coefficients between two-hourly Ps/c ratios with the daily mean $(0.558,0.076$ and 0.922 , respectively) indicated that single spot samples would be very unreliable. Assessment of the accuracy of three sampling regimens showed that accuracy of estimation of daily mean Ps/c ratio increased with increasing frequency of spot sampling, an observation which is consistent with studies evaluating the accuracy of spot sampling to assess daily mean molar ratios of purine derivatives to creatinine (Daniels et al. 1994, Chen et al. 1995). The minimum correlation coefficients demonstrate the worse-case scenarios (Table 4). On this basis, even the most intensive sampling regimen evaluated (four 4-h samples over two sampling days) would not be reliable as the $r$ values (between spot sample Ps/c and daily mean Ps/c determined by total urine collection) could be as low as 0.528 and 0.080 for treatments $\mathrm{SF}$ and $\mathrm{CD}$, respectively.

\section{Relationship between urinary pseudourid- ine excretion and $\mathrm{Ps} / \mathrm{c}$ ratios}

Prediction of daily pseudouridine excretion from daily mean Ps/c ratios obtained by a total urine collection was best achieved by scaling the ratios for live weight $(\mathrm{r}=0.700, \mathrm{n}=48, \mathrm{P}<0.001)$. A similar relationship has been reported between daily mean molar ratios of purine derivatives to creatinine and daily purine derivative excretion (Daniels et al. 1994). Between-cow variability in creatinine excretion was mainly responsible for the poor prediction of pseudouridine excretion indicating that creatinine fails as a marker of urinary output for individual cows, a finding which is in agreement with that of Dewhurst (1989). Current experimental data indicates that inaccuracies of the spot sampling technique makes this approach highly unreliable and that a total urine collection is required to assess accurately urinary pseudouridine excretion for an individual cow.

\section{Conclusions}

There was considerable diurnal variation in the molar ratio of pseudouridine to creatinine (Ps/c) in spot urine samples which was dependent on feeding system. None of the spot-sampling regimens evaluated gave reliable estimates of the daily mean Ps/c ratio. Daily mean Ps/c ratios could account for only half of the variation in daily urinary pseudouridine excretion largely due to between-cow variations in creatinine excretion. A total urine collection appears necessary to assess accurately urinary pseudouridine excretion in dairy cows.

Acknowledgements. K. J. Shingfield gratefully acknowledges receipt of a studentship provided by the Ministry of Agriculture, Fisheries and Food, UK. SAC receives financial support from the Scottish Office Agriculture, Environment and Fisheries Department. The authors also appreciate the statistical expertise provided by Mr. A. Sword and Mr. D. Hitchcock.

\section{References}

AFRC 1992. Technical committee on responses to nutrients, report number 9 . Nutritive requirements of ruminant animals: Protein. Nutrition, Abstracts and Reviews (Series B) 62: 788-835.
Alexander, R.H. 1969. The establishment of a laboratory procedure for the 'in-vitro' determination of digestibility. West of Scotland Agricultural College, research bulletin no. 42 . 
Vol. 7 (1998): 345-356.

Borek, E., Baliga, B.S., Gehrke, Ch.W., Kuo, C.W., Belman, S., Troll, W. \& Waalkes, T.P. 1977. High turnover rate of transfer RNA in tumor tissue. Cancer Research 37: 3362-3366.

Botts, R.L., Hemken, R.W. \& Bull, L.S. 1979. Protein reserves in the lactating dairy cow. Journal of Dairy Science 62: 433-440.

Chen, X.B., Grubic, G, Ørskov, E.R. \& Osuji, P. 1992. Effect of feeding frequency on diurnal variation in plasma and urinary purine derivatives in steers. Animal Production 55: 185-191.

-, Mejia, A.T., Kyle, D.J. \& Ørskov, E.R. 1995. Evaluation of the use of the purine derivative:creatinine ratio in spot urine and plasma samples as an index of microbial protein supply in ruminants: studies in sheep. Journal of Agricultural Science, Cambridge 125: $137-143$.

Daniels, Z.M., Chen, X.B., Kyle, D.J., Sinclair, K. \& Ørskov, E.R. 1994. Purine derivatives in urine and plasma of lactating cows given different levels of feed intake. Animal Production 58: Abstract 105.

Dewhurst, R.J. 1989. Studies on energy and nitrogen metabolism in the rumen-investigation of less invasive techniques for these studies. Ph.D. thesis. University of Bristol. p. 1.

- Mitton, A.M., Offer, N.W. \& Thomas, C. 1996. Effects of the composition of grass silages on milk production and nitrogen utilisation by dairy cows. Animal Science 62: 25-34.

Erb, R.E., Surve, A.H., Randal, R.D. \& Carverick, H.A. 1977. Urinary creatinine as an index of urinary excretion of estrogen in cows prepartum and postpartum. Journal of Dairy Science 60: 825-828.

Gabriel, K.R. 1962. Anti-dependence analysis of an ordered set of variables. Annals of Mathematics and Statistics 33: 201-212.

Gehrke, Ch.W., Kuo, C.W., Waalkes, T.P. \& Borek, E. 1979. Patterns of urinary excretion of modified nucleosides. Cancer Research 39: 1150-1153.

Gibb, M.J., Ivings, W.E., Dhanoa, M.S. \& Sutton, J.D. 1992. Changes in body components of autumn-calving Holstein-Friesian cows over the first 29 weeks of lactation. Animal Production 55: 339-360.

Gonda, H.L. \& Lindberg, J.E. 1994. Evaluation of dietary nitrogen utilisation in dairy cows based on urea concentrations in blood, urine and milk, and on urinary concentrations of purine derivatives. Acta Agriculturae Scandinavica, Section A, Animal Science 44: 236-245.

Kahn, M.S.N., Salim, M. \& Maden, B.E.H. 1978. Extensive homologies between the methylated nucleotide sequences in several vertebrate ribosomal ribonucleic acids. Biochemical Journal 169: 531-542.

Kenward, M.G. 1987. A method for comparing profiles of repeated measurements. Applied Statistics 36: 296308.

Lawes Agricultural Trust 1987. GENSTAT 5 Reference Manual. Clarendon Press, Oxford, UK.

MAFF 1975. Energy allowances and feeding systems for ruminants. Technical Bulletin 33. Ministry of Agriculture, Fisheries and Food. 79 p. London.

Martín Orúe, S.M., Balcells, J., Guada, J.A. \& Castrillo, C. 1995. Endogenous purine and pyrimidine deriva- tive excretion in pregnant sows. British Journal of Nutrition 73: 375-385.

-, Dapoza, C., Balcells, J. \& Castrillo, C. 1996. Purine derivatives excretion in lactating ewes fed straw diets with different levels of fish meal. Animal Feed Science and Technology 63: 341-346.

Minitab Inc. 1980. Minitab Data Analysis Software. Pennsylvania State University, Pennsylvania.

Moorby, J.M., Dewhurst, R.J. \& Marsden, S. 1996. Effect of increasing digestible undegraded protein supply to dairy cows in late gestation on the yield and composition of milk during the subsequent lactation. Animal Science 63: 201-213.

Oldham, J.D., Lobley, G.E., Konig, B.A., Parker, D.S. \& Smith, R.W. 1980. Amino acid metabolism in lactating dairy cows early in lactation. In: Oslage, H.J. \& Rohr, K. (eds.). Protein metabolism in Nutrition, EAAP No. 27, ICBL, Braunchschweig. p. 458-464.

Puchala, R., Shelford, J.A., Barej, W., Kulasek, G.W., Piòr, H., Keyserlingk, M.V. \& Makoni, N. 1993. Urinary excretion of pseudouridine and purine metabolites in ruminants. Journal of Animal Physiology and Animal Nutrition 69: 186-193.

Rosskopf, R., Rainer, H. \& Giesecke, D. 1991. Purin- und pyrimidinmetaboliten zur beurteilung des pansenstoffwechsels: HPLC-analysen in milch and blutplasma. Archives of Animal Nutrition 41: 411-426.

Sander, G., Topp, H., Heller-Schöch, G., Wieland, J. \& Schöch, G. 1986a. Ribonucleic acid turnover in man: RNA catabolites in urine as a measure for the metabolism of each of the three major species of RNA. Clinical Science 71: 367-374.

- , Hülsemann. J., Topp, H., Heller-Schöch, G. \& Schöch, G. $1986 \mathrm{~b}$. Protein and RNA turnover in preterm infants and adults: A comparison based on urinary excretion of 3-methylhistidine and of modified one-way RNA catabolites. Annals of Nutrition and Metabolism 30: 137-142.

Schöch, G., Heller-Schöch, G., Müller, J., Heddrich, M. \& Grüttner, R. 1982. Determination of RNA metabolism as indicator of nutritional status. Klinische Pädiatrie 194: 317-319.

Shingfield, K.J. \& Offer, N.W. 1998. Evaluation of the spot urine sampling technique to assess urinary purine derivative excretion in lactating dairy cows. Animal Science 66: 557-568.

Thomas, P.C. , Robertson, S., Chamberlain, D.G., Livingstone, R.M., Garthwaite, P.H., Dewey, P.J.S., Smart, R. \& White, C. 1988. Predicting the metabolisable energy (ME) content of compound feeds for ruminants. In: Haresign, W. \& Cole, D.J.A. (eds.). Recent advances in Animal Nutrition. London: Butterworths. p. 127-146.

Tiermeyer, W., Stohrer, M. \& Giesecke, D. 1984. Metabolites of nucleic acids in bovine milk. Journal of Dairy Science 67: 723-728.

Tilley, J.M.A. \& Terry, R.A. 1963. A two-stage technique for the in-vitro digestion of forage crops. Journal of the British Grassland Society 18: 104.

Weissman, S., Eisen, A.Z., Lewis, M., Karon, M. \& Clark, P. 1962. Pseudouridine metabolism. III. Studies with isotopically labelled pseudouridine. Journal of Laboratorial and Clinical Medicine 60: 40-47. 
Shingfield, K.J. \& Offer, N.W. Assessment of pseudouridine excretion by spot urine sampling

\title{
SELOSTUS
}

\section{Mahdollisuus lyhytaikaisen virtsankeruun käyttöön lypsylehmien virtsan pseudouridiinin erityksen määrittämisessä}

\author{
Kevin J. Shingfield ja N.W. Offer \\ Maatalouden tutkimuskeskus ja SAC Auchincruive, Iso-Britannia
}

Tutkimuksessa arvioitiin lyhytaikaisen virtsankeruun soveltuvuutta kokonaispseudouridiinierityksen määritykseen virtsassa. Kaksitoista useamman kerran poikinutta holstein-friisiläislehmää ruokittiin ristikkäiskokeessa kahdella eri koedieetillä kahden 14 päivän koejakson ajan. Toisella ruokinnalla lehmät saivat vapaasti säilörehua ja väkirehutäydennys annettiin kerta-annoksena (SF). Toisella ruokinnalla sama rehuannos syötettiin seoksena (CD).

Virtsan kokonaiskeräykset tehtiin 24 tunnin ajan 2 tunnin välein koejaksojen päivinä 11 ja 14 . Pseudouridiinin ja kreatiniinin eritys kullakin 2 tunnin jaksolla oli yhteydessä keräämisen vuorokaudenaikaan (pseudouridiini, $\mathrm{P}<0.001$ ja kreatiniini, $\mathrm{P}<0.05$ ) ja vaihteli lehmittäin (pseudouridiini, $P=0.092$ ja kreatiniini, $P<0.01$ ), mutta näytteenottopäivä tai lehmälle annettu dieetti eivät vaikuttaneet eritykseen. Pseudouridiinin ja kreatiniinin molaarinen suhde (Ps/c) vaihteli samalla tavalla vuorokaudenajan mukaan kuin pseudouridiinin erityskin. Aineistoa käyttäen määritettiin lyhytaikaisen virtsankeruun täsmällisyys Ps/c -suhteen päivittäisen keskiarvon ennustamisessa. Useampien näytteiden kerääminen saman päivän aikana osoittautui luotettavammaksi kuin näytteiden kerääminen useampina päivinä. Lyhytaikaisen keruun antaman ennusteen virhe oli suurempi CD-ruokinnalla kuin SF-dieetillä. Edes kaikkein intensiivisin näytteenotto-ohjelma ei antanut hyväksyttäviä ennusteita Ps/c -suhteen päivittäiselle keskiarvolle, pienimmän r-arvon ollessa 0.528 ja $0.080 \mathrm{SF}$ ja CD-ryhmissä. Lisäksi Ps/c -suhteen keskiarvo selitti vain puolet havaitusta pseudouridiinin erityksen päivittäisestä vaihtelusta. Kokonaisvirtsan kerääminen näyttääkin olevan välttämätöntä lypsylehmien päivittäisen pseudouridiinin erityksen täsmälliseksi määrittämiseksi. 